\title{
Square Pulse Galvanostatic Synthesis and Characterization of Nano- Copper Oxide
}

\author{
Hassan Karami ${ }^{1,2, *}$, Boshra Afshari ${ }^{2}$ \\ ${ }^{1}$ Department of Chemistry, Payame Noor University, 19395-4697, Tehran, I.R. of Iran \\ ${ }^{2}$ Nano Research Laboratory, Department of Chemistry, Payame Noor University, Abhar, Iran \\ *E-mail: karami_h@yahoo.com
}

doi: $10.20964 / 2017.02 .50$

Received: 27 June 2016/ Accepted: 28 August 2016 / Published: 30 December 2016

\begin{abstract}
In this study, the copper oxide nanoparticles are synthesized by the square pulse galvanostatic method (SPGM) through anodic oxidation of copper electrode in sodium sulfate solution. The released $\mathrm{Cu}^{2+}$ ions are precipitated slowly as $\mathrm{Cu}(\mathrm{OH})_{2}$ nanoparticles. In the temperature more than $40^{\circ} \mathrm{C}$, the copper hydroxide is decomposed to $\mathrm{CuO}$ nanoparticles. The electrochemical cell includes one copper positive electrode (anode) and two copper negative electrodes (cathodes) in the sodium sulfate solution as electrolyte. The effects of some parameters such as solution temperature, electrolyte concentration, pule time, relaxation time and pulse amplitude were studied and optimized. The optimum conditions for the electrosynthesis of copper oxide nanoparticles includes $1 \times 10^{-4} \mathrm{M}$ sodium sulfate solution, the square pulse amplitude of $20 \mathrm{~mA} \mathrm{~cm}$ ch $^{-2}$, pulse time of $2 \mathrm{~s}$, relaxation time of $1 \mathrm{~s}$ and temperature of $60^{\circ} \mathrm{C}$. The produced samples are filtered and washed 3 times with water and finally with acetone and then dried at $600^{\circ} \mathrm{C}$ for $1 \mathrm{~h}$. The prepared samples are characterized by SEM, TEM and XRD techniques. The experimental data show the optimized copper oxide sample includes uniform CuOnanorods with $35 \mathrm{~nm}$ average diameter and $550 \mathrm{~nm}$ average length.
\end{abstract}

Keywords: Square pulse, galvanostatic, electrosynthesis, copper oxide, nanorods.

\section{FULL TEXT}

(C) 2017 The Authors. Published by ESG (www.electrochemsci.org). This article is an open access article distributed under the terms and conditions of the Creative Commons Attribution license (http://creativecommons.org/licenses/by/4.0/). 